Espaço Aberto | Open Space

\title{
Covid-19, biossegurança e antropologia
}

\section{COVID-19, biosecurity and anthropology}

\section{Jean Segata*}

*Universidade Federal do Rio Grande do Sul - Porto Alegre, RS, Brasil jeansegata@gmail.com

https://orcid.org/0000-0002-2544-074 


\title{
Resumo
}

Sofrimento, ansiedades e incertezas estão por toda a parte em face da pandemia de Covid-19. Tem sido uma experiência impactante, contudo cada vez mais comum. Nas últimas décadas, diferentes domínios de interesse, como aquele das emergências sanitárias e do clima e da autonomia alimentar e do terrorismo, tiveram seus caminhos cruzados na mira de ações de Estado para a vigilância e o controle de humanos, animais, artefatos e ambientes. Esse movimento complexo tem semeado algumas críticas que articulam inúmeras preocupações contemporâneas. Elas performam o emergente campo da antropologia da biossegurança. O objetivo deste trabalho é fornecer uma introdução a esses debates e suas possibilidades de interseção com aqueles da antropologia da saúde, da ciência e da tecnologia, das relações humano-animal e ambientes e suas críticas a partir de conhecimentos e práticas locais.

Palavras-chave: Covid-19; biossegurança; saúde; antropologia.

\begin{abstract}
Suffering, anxieties and uncertainties are everywhere on the COVID-19 pandemic. It has been an impactful experience, however, increasingly common. Over the past few decades, different interests such as sanitary and climate emergencies, and food autonomy and terrorism, have crossed their paths with State actions for the surveillance and control of humans, animals, artifacts, and environments. This complex movement has launched some criticisms that raise contemporary concerns. They enact the emerging field of the anthropology of biosafety. The objective of this paper is to provide an introduction to these debates and their possibilities of intersection with those of health anthropology, science and technology, human-animal relations and environments and their criticisms based on local knowledge and practices.
\end{abstract}

Keywords: COVID-19; biosecurity; health; anthropology. 
Surtos, epidemias e pandemias não formam apenas tendências epidemiológicas. Como eventos críticos, eles expõem estruturas de sofrimento, injustiça e desigualdade. Eles reordenam relações e moralidades e também produzem sujeitos, subjetividades e novas políticas de coexistência (Das, 1995; Kelly; Keck; Lynteris, 2019; Manceron; Roué, 2009; Pimenta, 2019). Temos vivido isso com o novo coronavírus. Ele tem posto em relevo as muitas faces e os muitos custos daquilo que Bruno Latour (2020, p. 24) chamou de "uma profunda mutação em nossa relação com o mundo". Não se trata apenas da agudeza avassaladora da doença que o vírus pode provocar, a Covid-19. Trata-se do modo como a pandemia evidencia muitas camadas de vulnerabilidade. Elas se acumulam nas situações de desigualdade de acesso a serviços de saúde e de proteção social. Na fragilização do cuidado de si e do coletivo em face de incontáveis problemas socioeconômicos como a precarização do trabalho e o desemprego. Na necropolítica das inúmeras formas de racismo, exclusão e violência estrutural, sobremaneira aquelas manifestadas no robusto projeto de denegação que tem sido protagonizado por governos que combinam o neoliberalismo e o emergente extremismo de direita, como é o caso do Brasil. ${ }^{1}$

Tem sido complicado pensar o contemporâneo sem a Covid-19. Tanto é que o projeto original deste trabalho se limitava a produção de um breve estado da arte sobre o tema da biossegurança na antropologia. Mas as inúmeras perdas,

1 Ver, por exemplo, as inúmeras análises antropológicas sobre a pandemia que têm aparecido em iniciativas como a dos boletins publicados desde março pela Anpocs sob a rubrica "Cientistas Sociais e o Coronavírus". Eles estão disponíveis em https://www.anpocs.com/index.php/publicacoes-sp-2056165036/boletim-anpocs e trazem produções que mostram efeitos da Covid-19 situados nas experiências particulares e nas vulnerabilidades estruturais e não somente nos números e nos processos biológicos. Entre outros esforços dessa natureza estão ainda a série Dispatches from the pandemic, publicada pelo Somatosphere, reunindo trabalhos da antropologia médica e da saúde, disponível em http://somatosphere.net/series/dispatches-from-the-pande$\mathrm{mic} /$ e as publicações que têm saído sob a rubrica "Pensar la pandemia", do Observatorio Social del Coronavirus, da CLACSO, disponíveis em http://www.clacso.org.ar/biblioteca_pandemia/ (ambos acessados em 08/05/2020). A pandemia e seus efeitos também é o objeto do estudo que coordeno por meio da Rede COVID-19 Humanidades, intitulado A Covid-19 no Brasil: análise e resposta aos impactos sociais da pandemia entre profissionais de saúde e população em isolamento. A pesquisa responde a uma encomenda do Ministério da Ciência, Tecnologia, Inovações e Comunicações - MCTIC (Convênio Ref.: 0464/20 FINEP/UFRGS). A rede foi constituída em uma parceria entre pesquisadores e pesquisadoras da UFRGS, da Fiocruz, do Instituto Brasil Plural da UFSC, da Unicamp e da UnB. 
as dores e os sofrimentos, os conflitos e as incertezas associadas à pandemia afetaram a mim e a escrita do texto. Com o passar dos dias, ficou difícil não traçar algumas conexões entre ela e o tema original deste ensaio. Assim, passei explorar alguns quadros do debate sobre a biossegurança na antropologia, seus expoentes e tendências, com situações vividas nestes últimos meses, sobretudo o desenvolvimento inicial da pandemia. Não se trata, assim, de um estudo sobre a Covid-19, suas causas e seus efeitos devastadores. Tampouco se trata de uma análise histórica ou epistemológica mais ampla sobre o tema da biossegurança. Neste ensaio eu apresento alguns fios ainda soltos, mas que podem nos ajudar a costurar agendas de pesquisa sobre esses campos de interesse.

Eu começarei com uma breve narrativa de alguns acontecimentos iniciais que deram forma à pandemia. Eles ajudam a materializar o principal fantasma imaginado pelas políticas biossegurança: a catástrofe biológica em escala global. Na sequência, eu apresento alguns caminhos que se cruzaram nas últimas quatro décadas e que nos ajudam situar essa preocupação, mas também suas oportunidades. A saber, a emergência do aprimoramento da natureza facilitada pela engenharia genética. A globalização e sua aceleração da circulação de pessoas e do comércio mundial de produtos de origem vegetal e animal. E em consequência deles, os medos e ansiedades sobre a saúde e a segurança das fronteiras entre Estados-nação, mas também interculturais e interespécies. A minha ênfase se dará nos imaginários de antecipação, assepsia e de contenção. Elas mobilizam as chamadas novas inteligências epidêmicas presentes de forma robusta no universo atual da biossegurança, como também a recalcitrante militarização das relações entre humanos, animais, criaturas microscópicas e ambientes.

\section{Escrevendo com o vírus}

Quando eu comecei este texto, a China anunciava uma dezena de mortes por conta de uma nova doença. Eram meados de janeiro e ela se espalhava rapidamente. As expectativas para 2020 não incluíam uma pandemia, mas tudo mudaria. Por toda a parte, vidas, projetos e a própria história do presente seriam escritas com um vírus. O sinal de alerta foi um surto de pneumonia 
de causas desconhecidas. Os sintomas clínicos lembravam aqueles de um passado recente com a Sars e a Mers. Eles incluíam coriza, febre e dificuldade para respirar. Tratava-se de um novo coronavírus. ${ }^{2}$ Wuhan, capital da província de Hubei, na China Central, passou a ser considerada o epicentro. Autoridades isolavam aquela e outras cidades no entorno para evitar que a contaminação se espalhasse ainda mais e ampliavam o número de leitos disponíveis para 0 cuidado com os afetados. Hospitais de emergência eram erguidos em tempo recorde. Mas no Japão, na Tailândia, na Coreia do Sul e nos Estados Unidos os primeiros casos também se confirmavam, enquanto que no Brasil suspeitas ainda eram negadas pelo governo.

Pouco se sabia ainda sobre a nova doença, sua natureza e sua forma de contágio. Alguns falavam de cobras e morcegos como o seu reservatório. Outros desconfiavam dos frutos do mar e diversos comentários discriminatórios circulavam em redes sociais da internet, associando a doença ao que chamavam hábitos alimentares exóticos. Àquela altura, já era esperado que a Organização Mundial de Saúde (OMS) declarasse estado de emergência de saúde pública de interesse internacional (em inglês PHEIC - public health emergency of international concern). Mas seus experts não chegavam a um consenso. Para eles, era cedo demais. Há inúmeros interesses políticos e internacionais que mesclam tecnociência e mercado no campo da segurança global em saúde. Usualmente, eles se sobressaem às características epidemiológicas de uma doença (Lakoff, 2017; Marques; Silveira; Pimenta, 2020). Enquanto a distribuição de riscos e impactos e as suas oportunidades eram avaliadas pelos comitês de experts, as especulações se somavam às incertezas e espalhavam preocupação mundo afora. ${ }^{3}$

Em 30 de janeiro, o etíope Tedros Adhanom Ghebreyesus, primeiro homem negro a ocupar a posição de diretor-geral da OMS, anunciou a PHEIC. No seu discurso, ele acenou para caminhos de cooperação e solidariedade entre as nações.

2 Sars e Mers são, respectivamente, a síndrome respiratória aguda grave, que apareceu em 2002 na China, e a síndrome respiratória do Oriente Médio, identificado a partir da Arábia Saudita. Ambas as síndromes também são causadas por variedades de coronavírus - ver site da OMS: https:// www.who.int/csr/sars/en/ (acessado em 23/01/2020).

3 Ver, por exemplo, China... (2020); Guo, Luo e Gao (2020); Coronavirus death... (2020); Paciente... (2020). Ver ainda World Health Organization (2020a). 
Aquele seria o momento de confiar na capacidade técnica e científica do sistema de saúde chinês; de partilhar conhecimentos e experiências sobre o vírus, a doença e a vacina de forma aberta; de combater a disseminação de rumores e desinformação; e de evitar a restrição de circulação de pessoas e mercadorias em escala internacional (World Health Organization, 2020a). Contudo, mesmo diante dos apelos do diretor e em nome da segurança dos territórios nacionais e das suas populações, direitos individuais e coletivos começavam a ser afetados e se abriu espaço para estados de exceção, para o estigma, a desconfiança e a segregação em diversos níveis. A saúde das relações internacionais e das microrrelações do cotidiano também estavam sob ameaça. Quarentenas, repatriação de cidadãos e o fechamento de fronteiras internacionais com a China tornavam salientes as sensibilidades políticas e identitárias que se disfarçam sob o discurso frágil e generalista da globalização. Notícias de perseguição e afastamento a pessoas com "características orientais" começaram a se somar ecoando as recalcitrantes culpabilizações pelas epidemias - os pobres, os negros, os estrangeiros. Ainda no dia do anúncio da PHEIC, a OMS também apresentou o nome temporário doença aguda respiratória do 2019-nCoV. Mas na opinião pública, nas ruas e nas redes sociais da internet, o batismo veio antes: era a gripe da China causada pelo vírus chinês. Os vírus, como as pessoas, também são racializados e evocam materialidades e imaginários de exclusão e ódio (Mason, 2015, 2016). ${ }^{4}$ Poucos dias depois, a doença provocada pelo novo coronavírus (Sars-Cov-2) recebia então o seu nome oficial: Coronavirus disease ou simplesmente Covid-19, sem referências geográficas, como foi com a Mers, a febre do Nilo ou a gripe espanhola, no passado. ${ }^{5} \mathrm{O}$ mês de fevereiro fechou com cerca de 1,7 mil novos casos por dia, totalizando mais de 85 mil no mundo. Rapidamente, a escalada numérica ganhou força e a geografia da contaminação se alargou. A Europa se tornava o novo epicentro da doença. Depois, Nova Iorque. No dia 11 de março,

4 Nesta linha de pensamento, ver a interessante crítica da antropóloga Rosana Pinheiro-Machado (2020). Outras informações, ver, por exemplo, Países... (2020), Coronavírus: condomínio... (2020); Orgaz (2020).

5 Na manhã de 11 de fevereiro de 2020, pela sua conta do Twitter, a OMS anunciou o nome oficial como sendo Covid-19, sigla para "Coronavirus disease" e a indicação de seu ano de aparecimento, 2019. Ver https://twitter.com/WHO/status/1227248333871173632 (acessado em 11/02/2020). 
a OMS declarou que o mundo estava sob uma pandemia. E tudo aquilo era ainda apenas o começo. ${ }^{6}$

Os surtos da doença se multiplicavam e se espalhavam. As prioridades se dividiam. Em meio ao aumento na curva de casos e de vítimas fatais, as principais bolsas de valores decretavam circuit breaker e suspendiam suas operações: saúde e economia disputavam a pauta dos governos neoliberais. O preço do dólar e do barril de petróleo também apresentavam sintomas agudos de descontrole. Cortes de salários e reduções de postos de trabalho eram anunciados por todos, acrescentando ainda mais cargas de sofrimento a milhões de pessoas já expostas à pandemia. É que o capitalismo também é patológico. Suas crises se espalham mais rápido do que qualquer vírus e quase sempre atingem as populações mais vulneráveis. Em pouco tempo, a pandemia e as ações para a sua mitigação colocaram em relevo estruturas de desigualdade e de injustiça social. Ainda que corresse na opinião pública os dizeres de que o vírus não conhecia fronteiras ou classes sociais, a sua falsa democracia era desfeita nas evidências de que certas populações vivem mais expostas e experimentam de forma mais aguda e sem suporte os seus efeitos. Países mais ricos usaram do seu poder econômico para garantir para si os parcos estoques de equipamentos médicos e de proteção individual. Mais de um terço da população mundial entrou em estado de isolamento e houve corrida para comprar máscaras, mas também para conseguir porções mágicas de cura, como a cloroquina e os desinfetantes, defendidos em fake news de governos irresponsáveis e negacionistas. ${ }^{7}$ Uma miríade de crises sem precedentes em intensidade e proporção foi instalada. ${ }^{8}$

6 Ver UNA-SUS (2020) e OMS declara... (2020).

7 Ver Craveiro (2020) e Deus... (2020).

8 Até 29 de fevereiro havia apenas um caso de Covid-19 confirmado no Brasil. Entre idas e vindas e inúmeras interrupções, o presente tem sido vivido de forma triste e o futuro tem se mostrado ainda mais incerto do que quando eu comecei a escrever este texto. Em 20 de junho já eram mais de 1,5 milhão de casos confirmados e 50 mil mortes no país (Brasil..., 2020). No mundo, os casos confirmados já batiam a marca dos 10 milhões e as mortes alcançavam as 500 mil. Para acompanhar atualizações contínuas do número de casos nos mais de 210 países e territórios atingidos pela Covid-19 eu tenho consultado uma ferramenta do Google Notícias, o "Coronavírus (Covid-19)" em https://news.google.com/covid19/map?hl=pt-BR\&gl=BR\&ceid=BR:pt-419 (acessado em 20/06/2020). 
A Covid-19 tem sido impactante. Mas, alguns dos cenários que ela tem produzido não são totalmente novos. Resguardadas as particularidades e escalas eles ecoam dramas recentes vividos com o zika vírus no Brasil, com o ebola no continente africano, com as gripes suína e aviária na Ásia e com a doença da vaca louca na Europa. E eles não se restringem às epidemias. Há também as cartas com antraz, o ataque às Torres Gêmeas nos Estados Unidos e as suas intervenções militares no Oriente Médio, além da intensificação dos conflitos na Síria e na Faixa de Gaza. No início do século XXI, eventos descritos como ameaças em escala global têm se mesclado e mobilizado com mais intensidade às novas economias do risco, da preparação e da resposta. Caos e perdas irreparáveis para uns, oportunidades para outros.

Há singularidades epidemiológicas, legais, socioculturais, políticas, econômicas e ambientais envolvidas na constituição local desses eventos. Contudo, um imaginário cada vez mais abrangente tem moldado um projeto global que converte saúde e segurança em uma única commodity. Essa mudança de escala e de natureza tem sido frequentemente operada e justificada por uma ideia elástica de globalização. Nela cabe a expansão da produção e do comércio internacional de produtos de origem animal e vegetal, a circulação de pessoas, mas também de conhecimentos e técnicas da microbiologia. Trata-se de um cenário construído a partir de discursos catastróficos sobre células terroristas infiltradas entre migrantes e refugiados, superbactérias mutantes resistentes a antibióticos e cepas mortais de algum vírus adormecido que atravessa oceanos na carona de algum voo comercial (Caduff, 2014a, 2015; Collier, 2011; Collier; Lakoff, 2008). Assim, diferentes domínios de interesse, como aquele das emergências sanitárias e climáticas, da autonomia alimentar e do terrorismo, tiveram seus caminhos cruzados na mira de ações de Estado para a vigilância e o controle de humanos, animais, artefatos e ambientes. Esse movimento complexo tem semeado reflexões que articulam inúmeras preocupações contemporâneas sob a rubrica de uma emergente antropologia da biossegurança. O objetivo deste trabalho é fornecer uma introdução a esses debates e suas possibilidades de interseção com aqueles da antropologia da saúde, da ciência e da tecnologia e das relações multiespécie. 


\section{Biotecnologia, saúde e globalização}

A construção do campo da biossegurança articula diferentes disciplinas como a ecologia, a epidemiologia, a biotecnologia, a bioética, e as humanidades. A sua origem é difusa, mas há certa unanimidade em pensar que se trata de uma especialidade dedicada às ações de contenção de riscos inerentes à exposição a agentes biológicos potencialmente contaminantes. Inicialmente, essas práticas se remetiam às atividades em laboratório, mas aos poucos foram estendidas para os ambientes de saúde e também à indústria, ao comércio, à produção agrícola e às relações internacionais (Rocha et al., 2012). Em grande medida, 0 que estava em pauta era o avanço da microbiologia a partir da segunda metade do século XX e a sua acelerada unificação com outros campos da ciência, da tecnologia e de suas aplicações. Tal processo passou a exigir debates mais amplos sobre ética, processos laborais, preocupações ambientais e segurança dos ambientes e saúde (Neves et al., 2007; Rocha et al., 2012). Assim, protocolos, normas, leis e uma diversidade de documentos técnicos passaram a ser elaborados sob a rubrica da biossegurança, regulamentando práticas de pesquisa e intervenção, mas também de produção e circulação de artefatos biológicos. ${ }^{9}$

O ponto-chave é que tecnologias de manipulação da vida, tipicamente confinadas ao laboratório, passaram a ocupar espaço na criação de animais, no cultivo de plantas, nas práticas biomédicas e na vida cotidiana de uma maneira cada vez mais intensa. Em alguns casos, essas tecnologias se mesclaram a interesses militares de domínio de território e figuraram junto de tecnologias químicas e de manipulação nuclear no desenvolvimento de armas, sobretudo durante a Guerra Fria. Em outros, elas sugeriam cenários de ameaça à saúde diante da possibilidade de criação e propagação de agentes patógenos (Collier; Lakoff, 2008; Fidler; Gostin, 2008). Inúmeros questionamentos sobre

9 Ver, por exemplo, a norma reguladora $\mathrm{n}^{\circ} 32$, criada pela portaria n. 485 , de 11 de novembro de 2005, do Ministério do Trabalho e Emprego (Brasil, 2005b), que dispõe sobre a segurança e saúde no trabalho em serviço de saúde. Ela descreve e classifica os tipos de risco inerentes ao trabalho com agentes biológicos e o regramento para o cuidado e proteção do trabalhador. No contexto da atual pandemia de Covid-19, por exemplo, a proteção do trabalhador da saúde também está no centro das atenções já que o uso de equipamentos de proteção individual - EPIs, regrado nessa norma, tem sido prejudicado por um desabastecimento provocado tanto por investimentos precários na área da saúde como pelas disputas comerciais internacionais acentuadas pela pandemia. Ver, por exemplo, Lister, Shukla e Bobille (2020). 
intervenções, objetos e práticas que desafiavam os limites então imaginados entre o seguro e o inseguro - mas também o orgânico e o inorgânico, o natural e o modificado, o estável e o incerto, etc. - fizeram emergir debates sobre as múltiplas faces do risco - sua avaliação, seu manejo e sua comunicação (Donaldson, 2008). Mais do que isso, uma gramática transcultural do risco converteu-se em um modo de governar e de ser governado, inflou os sonhos tecnocráticos para sua distribuição e regulação e também se tornou um modo de pensar a ação social em um mundo incerto (Beck, 1992; Callon; Lascoumes; Barthe, 2001).

Foi nesse conjunto de interseções entre domínios da biotecnologia e da política que a antropologia também formou inúmeras agendas de pesquisa. A maior parte delas não reivindica a participação na formação de um campo específico sobre a biossegurança, mas as questões que elas têm levantado sobre os efeitos das manipulações genéticas e microbiológicas são de fundamental interesse para a constituição dele. É o caso do universo das modificações genéticas e o modo como ele amplificou o escopo das transformações operadas sobre o que tratamos como natureza. Depois de séculos de sua exploração como fonte de recurso e de tentativas de controle sob inúmeros meios de domesticação e macrotransformação, uma concentração em políticas de aprimoramento biológico passou a ser sustentada por uma espécie de governo das moléculas (Fischer, 2003; Rose, 2013; Sibilia, 2015). Exemplos e inspirações podem ser encontrados em importantes investimentos etnográficos que abriram caminhos para explorar as reconfigurações dos regimes de verdade do corpo, da sexualidade e do gênero, da identidade, da cidadania, dos diagnósticos de saúde e doença ou das relações de parentesco. Eles problematizam transformações introduzidas pelas tecnologias da vida, sobretudo a cotidianização do DNA, a pesquisa e o uso de células-tronco embrionárias ou o manejo dos hormônios (Cesarino, 2007; Fonseca, 2014; Franklin; Lock, 2003; Petryna, 2003; Richter, 2016; Rohden, 2008, 2019; Santos; Gibbon; Beltrão, 2012; Strathern, 2005). Outra linha de interesse nesse contexto da expansão da genômica é o da crítica antropológica às conversões da agricultura e da agropecuária em formatos de business e tech. Facilitadas por meio dos métodos de confinamento animal e da monocultura vegetal, essas atividades passaram a ser baseadas no emprego de organismos geneticamente modificados e organismos vivos modificados (em inglês, respectivamente, genetically modified organisms - GMO e living modified organism - LMO), nos defensivos químicos e nos antibióticos, como também nas 
disputas sobre as fronteiras biológicas e os limites do Estado (Bevilaqua, 2014; Blanchette, 2020; Cesarino, 2006; Déturche, 2012; Lapegna, 2019; Leal, 2016; Menasche, 2003; Sordi, 2015, 2017). ${ }^{10}$

Em um artigo que apareceu há quase duas décadas, Collier, Lakoff e Rabinow (2004) sugerem de forma mais específica que o tema da biossegurança seria um objeto que articularia métodos, conceitos e sentidos apropriados a uma antropologia do contemporâneo. $\mathrm{O}$ artigo ecoava uma intensa preocupação que transitava entre uma atenção à ex-União Soviética e os então recentes eventos de terrorismo no início do século XXI. Em saliência estavam as armas biológicas e os sistemas estadunidenses de biodefesa. ${ }^{11}$ Para Collier, Lakoff e Rabinow (2004), não havia consenso técnico para afirmar a associação entre construtores dessas armas e sua origem soviética e os possíveis eventos terroristas envolvendo o seu uso, como também não eram claras as demandas das novas políticas de imigração e de preparação e resposta no campo da saúde - temas esses que se mesclavam no conjunto das preocupações da época. Por isso, criou-se uma aura de urgência na formação de um aparato de biossegurança no país - e que, por conseguinte, passou a ser uma agenda "vendida" no formato questão de interesse global. Em meio a esse cenário, três programas de

10 Ainda sobre esse ponto, é importante destacar que o emprego de GMO foi também um dos principais elementos que constitui o debate para a aprovação da Lei da Biossegurança no Brasil (Brasil, 2005a). Grande parte dessa agenda foi motivada pela pressão do agronegócio para regularizar o então emprego ilegal de sementes transgênicas de soja vindas da Argentina para o sul do Brasil a partir do fim dos anos 1990.

11 É importante marcar a forte convergência entre o tratamento dado pelos autores à biossegurança com a obra de Michel Foucault, em especial seus tópicos sobre biopolítica e o modo como podemos condensar a sua amplitude em termos de "segurança, território e população" (Foucault, 2008 , 2010). Em outro artigo, Rabinow e Rose (2006, p. 197) resumem e atualizam essa relação em três pontos. Para eles, o que está em jogo é a atenção sobre (i) a produção de verdades sobre os seres vivos - e sua imbricação com a biologia, a demografia e a sociologia - e o modo como articulam novas linguagens de suscetibilidade nas relações contemporâneas entre genômica e risco; (ii) as estratégias de intervenção na existência coletiva em nome da saúde e da vida, algumas vezes em termos específicos de raça, etnicidade, gênero, religião, como também com foco em formas emergentes de cidadania genética e biológica; e (iii) os modos de subjetivação desses discursos e políticas e o modo como operam no suporte de formas interessadas de governo de si e dos outros. Contudo, a despeito dessa ligação com a obra de Michel Foucault e das limitações da ideia de vida presente nela e entre alguns de seus proeminentes críticos, como por exemplo Didier Fassin (2018), a biopolítica que interessa ao debate aqui proposto se estende para além dos humanos, e inclui a negociação dos limites epistemológicos e morais com animais, microrganismos e ambientes a partir de diferentes planos etnográficos, como será explorado mais adiante. 
pesquisa foram propostos na agenda de uma antropologia da biossegurança: (i) o exame dos esforços governamentais e não governamentais dos Estados Unidos para controlar cientistas soviéticos e seus trabalhos envolvendo armas e a manipulação de material biológico; (ii) a problematização do trabalho estratégico de modelagem de cenários de risco; e (iii) o trabalho de pesquisa das ciências da vida voltadas a identificar e responder ao aparecimento de patógenos desconhecidos que pudessem ser empregados como arma biológica (Collier; Lakoff; Rabinow, 2004, p. 6).

O referido artigo recebeu algumas críticas importantes. As principais questões levantadas nelas se remeteram à falta de clareza sobre "que tipo de vida manejada" poderia ser considerado um problema de segurança; com quais tipos de incerteza se estaria lidando; e o que caberia na gramática do terror - em particular, terror para quem, já que ele não seria uma coisa, mas uma relação (Helmreich, 2005). Além disso, a ideia de biossegurança que interessava ao programa estava mais concentrada no tópico dos riscos do que na discussão da própria segurança. Nas palavras de Langlitz (2005, p. 20, tradução minha): "Nunca há segurança na biossegurança, apenas risco. Biossegurança é um conjunto de práticas que tentam gerenciar riscos nas fronteiras onde pessoas, natureza, nações e conhecimento são ameaçados ou representam ameaças." Essas críticas levantavam dúvidas sobre a possibilidade concreta de se fazer etnografia desses aparatos de biossegurança sem um forte exercício metodológico que problematizasse a situacionalidade e reflexividade. Afinal de contas, a biossegurança era tratada por Collier, Lakoff e Rabinow (2004) como um tópico que espelhava o contemporâneo, mas se desenhava muito mais como um tema de interesse dos Estados Unidos e da maneira como aquele país reagia às pessoas, seres e produtos que chegavam do exterior às suas fronteiras. ${ }^{12}$

De toda forma, as agendas do artigo prosperaram, sobretudo a terceira delas, que se referia aos sistemas de atenção aos agentes patógenos. Políticas de biossegurança então ganharam forma, principalmente, em estratégias que articulavam globalização e saúde. Como sugere Cueto (2015), esse encontro fomentou a emergência de debates no campo da saúde global. Ela amplificou os propósitos

12 Para trabalhos que discutem as agendas que se referem ao controle de fronteiras, imigrantes ou suspeitos de envolvimento com o terrorismo por meio de tecnologias digitais, ver, por exemplo, Ceyhan (2010) e González (2015). 
da saúde internacional surgida no início do século XX e se vinculou à globalização e seus processos mundiais, que no mundo pós-Guerra Fria se caracterizaram pelo rápido incremento de fluxos comerciais e de viajantes, capitais financeiros e internet, além de uma exponencial neoliberalização dos Estados. ${ }^{13}$

A saúde global tem sido pautada pela ideia de uma transculturalização de evidências científicas. Elas buscam se impor como um "novo paradigma na arena político-sanitária internacional”. Por conseguinte, elas são mobilizadas como "critério de justificação e intervenção sobre os sistemas de saúde nacionais de saúde, sobretudo entre os países pobres e em desenvolvimento" (Matta; Moreno, 2014, p. 10). Exemplos dessa torção na saúde podem ser notados no tempo presente, com as preocupações em torno da Covid-19.

Dados sobre a mecânica de atuação do novo coronavírus começavam a ser produzidos desde os primeiros casos em Wuhan, na China. Eles resultavam das primeiras informações sobre os sintomas e o tratamento da doença, mas também sobre os números de casos de cura e de morte. Números indicavam que a taxa de letalidade era menor do que nas experiências com a Sars e a Mers, ainda que seu índice de transmissibilidade fosse mais alto (Zhang et al., 2020). Pessoas idosas com históricos de diabetes, hipertensão, cardiopatias ou obesidade pareciam mais propensas a desenvolver formas agudas da doença. Jovens e crianças pareciam mais resistentes e até mesmo assintomáticos. A doença ganhava uma forma e fórmulas derivavam dela. A questão é que as informações locais que produziram esses primeiros dados tiveram as suas escalas amplificadas no mesmo ritmo de expansão geográfica e numérica da contaminação, que foi muito rápido. A decretação da pandemia fez com que o novo coronavírus fosse convertido em um problema em escala global e algumas das primeiras formas de enquadrá-la ganharam um estatuto de referência. Acontece que números, tecnologias e escalas viajam por toda a parte e fingem universalidade (Adams, 2016; Biruk, 2018; Pereira, 2020; Segata, 2020a; Tsing, 2005; Von Schnitzer, 2013). Em outros termos, o problema é que, ainda que

13 É interessante notar como uma tendência de formação e pesquisa em saúde global ganhou força nos Estados Unidos após os ataques às Torres Gêmeas em Nova Iorque. Exemplos disso são os programas que foram constituídos em algumas das principais universidades do país, como é o caso da Columbia University (2003), Princeton University (2008), Brown University (2009) ou Harvard University (2011). 
haja uma mecânica biológica mais ou menos padronizável e conhecimentos e técnicas para o seu manejo, situações locais de injustiça e de vulnerabilidade social e as próprias experiências de saúde e doença ou aquelas de risco e cuidado tensionam e limitam essa universalidade. Uma doença como a Covid-19 pode se converter em fenômenos de escala global, mas tanto o global como as doenças e as suas escalas são atuações que se realizam a partir de materialidades, práticas e sentidos singulares e até mesmo contingentes (Mol, 2002; Segata, 2020a).

A questão aqui posta, como alertam Matta e Moreno (2014), é que, ao dividir conhecimentos, indicadores, avaliadores e ranqueamento de necessidades de um lado e pessoas, políticas locais e culturas - desterritorializadas, mensuradas e hierarquizadas - de outro, a saúde global toma como parâmetro o pensamento ocidental hegemônico e atualiza versões regulatórias e colonizadoras do conhecimento científico. ${ }^{14}$ Nesse caminho, como notam Collier e Lakoff (2008), foi baseada também nesses enquadramentos que confundem globalização e universalidade que a OMS passou a reconfigurar os limites espaciais e temporais das abordagens de saúde, alimentação e terrorismo. No início do século XXI simplesmente parar a doença nas fronteiras nacionais passou a ser visto como algo inadequado e fomentou a ideia de que é necessário estar preparado com antecedência para ameaças desconhecidas (Collier; Lakoff, 2008, p. 8). Foi por meio dessa questão que se abriu o campo para uma problematização antropológica da conversão da saúde em tema de segurança, como também da emergência das novas inteligências epidêmicas.

14 Nesse sentido, cabe ainda notar que uma parte importante do debate público contra a disseminação das chamadas fake news também endossa o colonialismo intelectual que converte o conhecimento científico em sinônimo de verdade universal. Exemplo disso pode ser visto em Domingos (2020). O consumo de chás, ervas, mel, etc., algumas vezes associado a práticas religiosas, de estilo de vida ou mesmo médicas, compõe um vasto repertório de conhecimentos e tradições culturalmente situadas (Langdon; Follér; Maluf, 2012). Contudo, parece que a veiculação de notícias falsas na internet sobre os mais variados temas tem também operado uma atualização de um reducionismo polarizado entre ciência e senso comum no campo da saúde/doença. Com ele, experiências e práticas terapêuticas de cuidado de si não institucionalizadas têm sido tratadas na chave do que é falso, enquanto que a verdade tem sido associada ao conhecimento biomédico e suas práticas de medicalização. 


\section{Bolas de cristal}

Em uma coletiva de imprensa no início de março de 2020, o então ministro da Saúde, Luiz Henrique Mandetta, foi questionado sobre o que poderíamos esperar da Covid-19. Ele analisou as previsões estatísticas, alguns gráficos, mapas e muitos números apresentados em Powerpoint e respondeu: "Tudo está acontecendo dentro do que imaginamos, mas não temos uma bola de cristal. Estamos trabalhando com as informações mais recentes. Por mais difícil que seja, não é a primeira epidemia que enfrentamos" (cf. Souza, 2020, grifo meu). De fato, o Brasil sofre com grandes epidemias desde os últimos dois séculos. Mas restam inúmeras dúvidas de que esses antecedentes garantam qualquer solução para os desafios atuais da Covid-19. Afinal, muito mais do que lições que produzam ações preventivas que corrijam problemas detectados, índices históricos têm sido cada vez mais utilizados como medidas de classificação do presente do que de projeção futura (Segata, 2020b).

A despeito de importantes iniciativas de saúde pública no Brasil, como o caso do SUS e também da alta competência de pesquisa no campo da saúde, há um importante e crônico desinvestimento em ciência e um crescente distanciamento entre ela e a elaboração de medidas pontuais e de políticas públicas abrangentes. No âmbito da preparação e resposta no Brasil, Carmo, Penna e Oliveira (2008), por exemplo, mostram como a implantação da Rede Nacional de Alerta e Resposta às Emergências em Saúde Pública (Rede Cievs) auxiliou na mitigação de danos provocados por doenças infecciosas, zoonoses e mesmo por catástrofes climáticas. Ela opera por meio de um amplo e capilarizado sistema de notificações, mas também de uma contínua implantação de sentinelas baseadas em tecnologia de informação, em sinergia com um dos mais amplos sistemas públicos de saúde, o SUS. ${ }^{15}$

O ponto crítico é o de que há um robusto emprego de tecnologias ditas de antecipação sob a rubrica da biossegurança. Elas têm feito com que conhecimentos e práticas locais de prevenção, cuidado, mas também de formulação

15 Contudo, cabe notar que no mesmo país, e em contraste a um investimento positivo como o do SUS, e mesmo diante de evidências científicas sobre a ineficácia e riscos inerentes, o presidente Jair Bolsonaro insiste no emprego da "cloroquina" para o tratamento da Covid-19 combinado com tentativas de desfazimento do isolamento social, amplamente defendido pelas autoridades de saúde. Por exemplo, ver Valfré e Vargas (2020) e Bolsonaro... (2020). 
da própria vida cotidiana, sejam suplantados por políticas de preparação e resposta, cuja atuação em problemas presentes tem sido minorada em razão do comércio de um futuro imaginado. O quadro a seguir, extraído de Lakoff (2008, p 37, tradução minha), nos ajuda a sintetizar esse imaginário e forma um guia para a reflexão:

\begin{tabular}{|c|c|c|c|}
\hline & $\begin{array}{c}\text { Segurança } \\
\text { da soberania do } \\
\text { Estado }\end{array}$ & $\begin{array}{c}\text { Segurança } \\
\text { das populações }\end{array}$ & $\begin{array}{c}\text { Segurança } \\
\text { de sistemas vitais }\end{array}$ \\
\hline $\begin{array}{l}\text { Momento de } \\
\text { articulação }\end{array}$ & $\begin{array}{l}\text { Século XVII, } \\
\text { monarquias }\end{array}$ & $\begin{array}{c}\text { Século XIX, higiene } \\
\text { urbana }\end{array}$ & $\begin{array}{c}\text { Meados do século XX } \\
\text { defesa civil }\end{array}$ \\
\hline $\begin{array}{l}\text { Racionalidade } \\
\text { normativa }\end{array}$ & Interdição & Prevenção & Preparação \\
\hline Tipos de ameaça & Adversários & $\begin{array}{l}\text { Eventos de ocorrên- } \\
\text { cia regular }\end{array}$ & $\begin{array}{l}\text { O imprevisível, even- } \\
\text { tos potencialmente } \\
\text { catastróficos }\end{array}$ \\
\hline $\begin{array}{l}\text { Formas exemplares } \\
\text { de conhecimento }\end{array}$ & Estratégia & $\begin{array}{l}\text { Epidemiologia, } \\
\text { demografia }\end{array}$ & $\begin{array}{l}\text { Performances } \\
\text { imaginativas }\end{array}$ \\
\hline Operação & $\begin{array}{l}\text { Deter ou defen- } \\
\text { der-se do inimigo }\end{array}$ & Risco distribuído & $\begin{array}{l}\text { Medir a vulnerabili- } \\
\text { dade, desenvolver } \\
\text { competência }\end{array}$ \\
\hline
\end{tabular}

Quadro 1. Formas de segurança coletiva.

O quadro de Lakoff (2008) articula períodos-modelo que desdobram a noção de biopolítica de Michel Foucault $(2008,2010)$ em biossegurança e como ela ilumina pensamentos e práticas emergentes no campo da saúde e de suas políticas. No quadro, o século XVII, por exemplo, é caracterizado como o momento de articulação dos Estados-nação modernos (sobretudo os europeus e suas colônias) cuja soberania deveria ser garantida pela interdição do território. A ameaça a essa soberania é externa - representada por outros Estados em disputa que figuram como adversários ou inimigos e que devem ser administrados 
por meio de estratégias fundadas em inteligência militar. Em meados do século XIX, com os territórios ligeiramente garantidos contra a ameaça externa, emerge o tempo de promover a estabilidade interna. O que preocupava era a ocorrência de eventos regulares, como os conflitos civis, a fome, a luta de classes, mas também as irrupções epidêmicas emergentes. Nessa perspectiva, o risco passa a ser distribuído entre novos agentes como a economia, o mercado e o desemprego, os fenômenos climáticos e os microrganismos. Sobre eles, disciplinas como a epidemiologia e a demografia emergem com suas políticas de prevenção amplamente características do paradigma higienista: é o tempo de "excluir pobres e micróbios do social" - perigosos à integridade da nação. Por fim, o quadro mostra como uma segurança dos sistemas vitais emerge a partir de meados do século XX. Ela evidencia modelos de defesa civil já historicamente enquadrados por pensamentos bélico-militares e cuja racionalidade tensiona a interdição e a prevenção para um investimento em preparação: é o tempo de "estar sempre pronto". O risco em evidência é o imprevisível catastrófico que está por vir e que é amplificado pela ideia de escala global. O conhecimento elaborado para sua mitigação é baseado nas performances imaginativas que, para usar uma expressão de Gerda Reith (2004), "colonizam o futuro". Esse amanhã colonizado pelo risco imaginado e pela incerteza é o que sustenta o presente da indústria de medição de vulnerabilidade e de comércio deste híbrido saúde-segurança.

Ainda que o quadro de Lakoff (2008) lance importantes pistas para a compreensão da biossegurança, ele não deve tomado de maneira prescritiva. A linearidade e a aparente homogeneidade das políticas e práticas que ele caracteriza são sobrepostas ou combinadas em contextos locais, ainda que, quase sempre, importem problemas e soluções do norte para o sul global. Etnografias recentes nos ajudam a colocar a disposição do quadro em tensão, como o faz o seu próprio autor em um trabalho mais recente. A partir de um exame das medidas tomadas pela OMS em relação às crises com o ebola e com o zika, Lakoff (2017) se pergunta sobre o que significa estar preparado. Para ele, a ideia de preparação constitui uma espécie de biopolítica do tempo real. Ela é alimentada por uma profusão de tecnologias que produzem informações que não informam propriamente, mas que produzem imaginações sobre as quais se passa a agir e governar. No contexto da atual pandemia de Covid-19 a crítica de Lakoff (2017) ganha relevo e nos ajuda a situar a biossegurança como sendo aquilo que ele 
e Caduff $(2014 a, 2015)$ traduzem como uma modalidade emergente de governamentalidade. Ambos destacam o papel do afeto, das incertezas e indeterminações, mas também da tecnologia e da burocracia na sua produção.

Como escreveu Keck (2010, p. 42, tradução minha) em sua etnografia sobre a gripe aviária em Hong Kong,

o conceito de preparação não designava mais, como no caso da prevenção, a delimitação de um espaço vestido de séries estatísticas, tampouco como na precaução, a avaliação de riscos no tempo de ação: [a preparação] abrangia um conjunto de exercícios que pretendia fingir que o desastre já estava lá para limitar seus efeitos. Não era mais um trabalho empírico de negociação de limites ou um trabalho intelectual de avaliação de riscos, mas um trabalho da imaginação para se colocar coletivamente no horizonte da catástrofe.

Ferramentas como aquelas mencionadas na coletiva do ministro, como mapas dinâmicos elaborados por softwares de geolocalização, sistemas de mineração de dados, controle de telefones celulares, estatísticas, quadros, curvas, etc., cada vez mais comuns, fornecem elementos para que epidemiologistas, mas também economistas e políticos, definam e distribuam de forma desigual o risco e suas formas de contenção. Como assinala Caduff (2014b), tomadas de decisão no campo da biossegurança são feitas a partir de uma série de evidências em construção, rumores em investigação e intensa comunicação incompleta. Nas palavras de Caduff (2014b, p. 40-41, tradução minha, grifo meu),

Há sempre algo que está faltando, há sempre algo que está ausente, há sempre algo que está fora de alcance. [...] Estamos lidando com cientistas que estão compartilhando informações "quando elas estiverem disponíveis". Trata-se de "histórias incomuns" que estão "sem credibilidade". Estamos lidando com um "iceberg", mas ninguém sabe o quão grande ele é realmente. Trata-se de "rumores", que exigem confirmação oficial. Trata-se de "investigação adicional" e "estudos adicionais" que são "difíceis de ler". Trata-se de um padrão "que ainda precisa ser elaborado". Estamos lidando com "conversas de mídia social"; com um micróbio que está em movimento. A natureza está tentando nos dizer algo, mas ninguém tem ideia do que é. [...] Parece que isso é "inteligência epidêmica" [...]. O que essa "inteligência" oferece são informações, mas essas informações não podem nos 
informar. São obscuras, suspeitas, incertas, ambíguas, deficientes, inadequadas, indeterminadas. O objetivo dessas informações não é estabilizar a situação; pelo contrário, seu objetivo é desestabilizá-la e, ao fazê-lo, gerar uma cena de saturação [eventfulness]. [Com ela] a impossibilidade de representação é performada e essa performação constitui um tipo particular de prática.

Essa política da incompletude cria condições que possibilitam muitas estratégias de intervenção, mas também de absolvição dos seus próprios insucessos. Há sempre alguma coisa que pode ser um sinal, e cada sinal precisa ser decodificado - como uma sopa de morcego com carne de cobra ou um vestígio de vírus nos esgotos de uma cidade. ${ }^{16}$ Eles podem relevar "a verdade" ou levar a lugar algum. Mas nunca não são nada à medida que, ainda que incompletos, eram sinais. São eles que justificam as medidas tomadas, como as intervenções antecipadas, baseadas em projeções. Muitas vezes, essas projeções ressoam mais os juízos dos programadores de algoritmos, e suas fantasias confusas de morte em massa que mimetizam o imaginário distópico de séries de televisão, do que as sensibilidades sobre como agir numa situação de emergência em realidades plurais e desiguais. ${ }^{17}$

Na pesquisa que fiz sobre as políticas de controle da dengue essa situação era evidente. A doença é transmitida pelo mosquito Aedes aegypti. Armadilhas para a sua coleta ou a dos seus ovos eram utilizadas para produção de dados entomológicos que alimentavam os softwares de vigilância. Elas quase sempre eram colocadas nas comunidades mais pobres. As autoridades encontravam

16 Há um campo vasto a ser explorado. Inúmeras podem ser as interseções, limites, mas também atuações possíveis, com informações que podem ser fake news, ruídos, meias-verdades, negacionismo ou ciência produzindo dados que ainda estão incompletos. Em uma busca simples, por exemplo, coexistem os mais distintos "indicativos de sinais", anunciados assim: "Coronavírus pode ter sido transmitido por sopa de morcego e carne de cobra" (Coronavírus pode..., 2020) ou "Esgoto pode indicar percentual de contaminados pela covid-19" (Peduzzi, 2020).

17 Nessa linha ver também Kelly, Keck e Lynteris (2019). Para os autores, uma antropologia das epidemias tem ajudado colocar em relevo os contornos geopolíticos e as consequências da biossegurança. Para eles, a ideia de ameaça iminente perene fornece o pretexto para a expansão do poder governamental sobre todas as formas de vida, como também para restringir o escopo da prática de saúde pública. Esse processo prioriza os riscos que são projetados sobre "eventos contagiosos catastróficos imaginados", em vez de agir sobre "as desigualdades sociais cotidianas e as desigualdades globais que determinam quem é infectado em primeiro lugar" (Kelly; Keck; Lynteris, 2019, p. 4, tradução minha). 
mosquitos, mas apenas onde queriam encontrá-los. Portanto, as tecnologias de geolocalização ecoavam os círculos históricos de exclusão que associavam pobreza e doença (Segata, 2017, 2019). Nas porções territoriais mais pobres dos municípios não havia contêineres na rua para o depósito adequado de lixo; noutros casos, muitas pessoas acumulavam materiais recicláveis para vender com forma de sustento, na falta de empregos formais. A falta de água nas comunidades também era crônica e exigia que as pessoas improvisassem reservas dela em baldes. Em alguns casos, baldes e materiais recicláveis tornavam-se criadouros de mosquitos. As pessoas que conviviam com eles então passavam a ser responsabilizadas pela facilitação da contaminação, quando na verdade sofriam com os problemas estruturais que os expunham à falta de acesso a direitos fundamentais.

A própria noção de biossegurança era controversa nesse contexto de pesquisa. Grande parte da responsabilidade dos agentes de endemia que atuavam no controle de mosquitos era a de fornecer informações para alimentar as tecnologias de preparação. Mas eles mesmos não tinham disponível para si a proteção necessária para o trabalho. Não havia roupa adequada, filtro solar, nem repelente, tampouco luvas para o manuseio dos produtos químicos. Como costumavam dizer em Natal, uma das cidades onde fiz trabalho de campo, "o melhor EPI [equipamento de proteção individua] é ficar doente mesmo, porque daí você fica imune". Todos os agentes com quem eu trabalhei lá já haviam contraído dengue, zika ou chikungunya durante o trabalho. Em alguns casos, mais de uma doença.

Além disso, havia um outro "viés" na produção de dados para as tecnologias de preparação: o mosquitocentrismo (Augusto et al., 1998; Segata, 2017). Febre amarela, dengue, zika e chikungunya são doenças diferentes, mas o mosquito é o que formata grande parte da resposta em saúde. Quase sempre é ele o alvo. A maior parte das ações é resumida em combate a mosquitos com enormes porções de veneno. $O$ ponto é que as pessoas já sofriam com as doenças e com a falta de tratamento. Elas também eram expostas a problemas de abastecimento e saneamento básico e à falta de políticas públicas continuadas. Como mostram Diniz e Brito (2018) para o caso da zika, por exemplo, a epidemia nunca termina. Basta considerarmos as mulheres que se converteram em cuidadoras em tempo integral das crianças que desenvolveram síndrome congênita da zika, cuja característica mais evidenciada foi a microcefalia. Basta considerar as "terapias de estrada" - ou seja, os longos trajetos percorridos em busca de atendimento 
e cuidado básico especializado ou as disputas judiciais para conseguir benefício de saúde no INSS. A sensibilidade das bolas de cristal nunca capturava tanto sofrimento (Segata, 2020b). O que alimenta os softwares das tecnologias de preparação e resposta não são essas histórias. Neles, entram apenas as quantidades de ovos, mosquitos, criadouros, domicílios visitados, veneno utilizado ou casos notificados. Biografias e projetos de vida não pesam e são invisibilizados pela contabilidade numérica em torno dos mosquitos (Nading, 2017).

O que se nota, assim, é que as tecnologias de preparação não implicam, necessariamente, estarmos informados e materialmente prontos para não sofrermos os efeitos de uma crise sanitária. Antes, elas formam um emaranhado de elementos negociáveis que podem fundamentar tomadas de decisão mais ou menos precárias, empregadas para o governo da vida. Entre elas, como no caso atual da Covid-19, o estabelecimento de medidas de isolamento e sua rigidez, a decretação de rodízios de veículos, o fechamento de estabelecimentos comerciais ou o uso de máscaras de proteção. Todas amplamente disputadas entre (des)vontades políticas.

O ponto é que quando uma catástrofe, de fato, está instalada, a imaginação da preparação não dá conta da contingência dos acontecimentos e ficamos sem resposta. Nesse sentido, e seguindo o raciocínio de Lakoff (2017), a profusão de cenários de catástrofe forjados pela combinação de múltiplas camadas e sentidos de informação e imaginação intencionada serve muito mais para precificar a vida e do que para protegê-la. Em outras palavras, a ideia de preparação tem sido sequestrada por políticos neoliberais e pelas corporações atuariais. Ela fornece a eles muitos subsídios para justificar a privatização de sistemas de saúde e definir valores de seus planos e seguros. Mas oferece pouca resposta para evitar o sofrimento e a morte de certas porções da população expostas às injustiças sociais e às desigualdades estruturais, mais concretamente atingidas pelas crises sanitárias.

\section{Guerras crônicas}

“Temos um inimigo invisível." “A nossa segurança está ameaçada." “Não mediremos forças para vencer mais esta batalha." Frases como estas poderiam descrever situações de guerra, mas foram pinçadas entre noticiários sobre 
"o avanço do perigo" da Covid-19. Mesmo a OMS, na conferência de 11 de fevereiro de 2020 na qual se anunciou o nome oficial da doença, usou essa gramática. Para o diretor-geral da organização, o cenário era comparável a uma ameaça de terrorismo:

É uma questão de convulsões políticas, sociais e econômicas. [Uma epidemia] pode afetar todas as áreas da sociedade e é por isso que temos que leva-la a sério. O mundo, quando fala sobre terrorismo - imaginem -, o nível de preparação, e assim por diante, é imenso. Para ser honesto, um vírus é mais poderoso na criação de convulsões políticas, econômicas e sociais do que qualquer ataque terrorista, acredite ou não. Eu era ministro das Relações Exteriores e discutia o terrorismo e assim por diante, mas um vírus pode ter consequências mais poderosas do que qualquer ação terrorista, e isso é verdade. Se o mundo não quiser acordar e considerar esse vírus inimigo como inimigo público número um, acho que não aprenderemos nossas lições. É o inimigo número um do mundo e de toda a humanidade e é por isso que temos que fazer tudo para investir em sistemas de saúde, investir em preparação, e é por isso que eu sempre digo: é isso que me acorda à noite e deve acordar todos nós. [O vírus] é o pior inimigo que você pode imaginar. Pode causar estragos políticos, econômicos e sociais. (Tedros Adhanom Ghebreyesus, diretor-geral da OMS, 11 de fevereiro de 2020, tradução minha). ${ }^{18}$

As palavras do diretor-geral da OMS são emblemáticas para ilustrar o modo como os domínios da biossegurança têm militarizado as orientações do campo da saúde. Uma agenda de saúde pautada em termos de segurança e globalização tem feito emergir a ideia de que a patogenicidade é intensificada por meio da circulação acelerada de potenciais inimigos desconhecidos, presentes entre humanos, animais, ambientes e suas transformações tecnológicas. Com efeito, regulações e responsabilidades acionam a gramática das ameaças globais colocando em relevo os sintomas de uma guerra crônica. Ela performa e defende fronteiras entre certos humanos e entre eles e o resto do mundo e sustenta a razão das políticas de biossegurança com suas vontades de contenção e assepsia.

18 Ver World Health Organization (2020b). Todas as transcrições dos pronunciamentos oficiais da OMS estão disponíveis no seu website. 
Há dois fronts destacados - o do recurso e o da ameaça. Ambos integram, digamos assim, um enquadramento extenso do pensamento euro-americano afunilado pelo capitalismo - dito assim, entre naturalismo e Capitoloceno (Descola, 2017; Haraway, 2015). Trata-se do excepcionalismo humano que organiza o assim chamado mundo natural como sendo uma externalidade ao social (Lewgoy; Segata, 2017; Tsing, 2019). A partir dele, a natureza é convertida em uma fonte de recurso, imaginada como inesgotável. Referências a isso podem ser notadas na comoditização e o desejo de aprimoramento, com exemplos que vão da mineração ao desmatamento e do cultivo de monoculturas à produção intensiva de carne. Nesse imaginário, a natureza precisa ser domada, amansada e, por meio dos avanços da engenharia genética, ela deve ser melhorada. O controle total é a base de ajuste para que o planeta seja convertido em uma imensa plantation que atenda às necessidades do lucro, mais do que às necessidades do consumo em si. Em termos diretos, são histórias conturbadas com o mundo baseadas desde a relação como cultura até a cultura como business. $\mathrm{O}$ que se nota em exemplos cada vez mais triviais, como no caso da agricultura e sua conversão em agronegócio; e isso não é apenas uma mudança de termos, mas de pensamento, ações e valores. Essa emergente racionalidade "agro é tech" promete alimentar um mundo cada vez mais populoso e faminto, quando na verdade expande as escalas de lucro do capitalismo com cultivos otimizados pela combinação de aprimoramento genético e mão de obra precarizada.

Como assinalam Lapegna e Otero (2016), os cultivos transgênicos têm transformado a produção agrícola em diversas partes do planeta e foram adotados pela globalização neoliberal. Eles são criados, comercializados e patenteados por multinacionais, e costumam sofrer resistência e oposição de movimentos sociais e ONGs. Esses cultivos globais, assim, delineiam geografias desiguais dentro e entre países e expressam regimes tecnoprodutivistas que podem ser vistos como commodities - ou seja, bens criados para a geração do lucro.

Nessa mesma esteira, também podemos situar o movimento global da carnificação como sendo outra face ambígua e perversa do neoliberalismo agroalimentar facilitado pela biossegurança. Ele converteu animais em matéria-prima para a fabricação de "alimentos ricos em proteína" jogando com a popularização do consumo de carnes e a promessa da democratização alimentar em países economicamente vulneráveis (Lapegna; Otero, 2016). Gado, porco, frango 
e alguns peixes - criados em larga escala sob confinamento - ingressam na agenda de novos movimentos sociais político-dietéticos, ao passo que também se convertem em problemas ecológicos que afetam as mudanças climáticas (Blanchette, 2020; Lapegna, 2019; Lien, 2015).

O ponto é que no front da natureza como recurso a expansão da dieta industrial baseada no aprimoramento e na comoditização tornou-se uma peça-chave para a mercantilização da força de trabalho. "Quanto mais baixo for o preço dos alimentos, menor é a pressão que enfrentam os capitalistas por parte dos trabalhadores para aumentar salários e maior é a mais-valia obtida, que faz ampliar os lucros" (Lapegna; Otero, 2016, p. 24, tradução minha). Ao passo disso, ela abre novas frentes de expansão de mercados com a emergente epidemia não vetorial de doenças crônicas associadas a dietas e estilo de vida, como o que decorre com o consumo de açúcar (Moran-Thomas, 2019). Além disso, o trabalho precário da indústria da carne tem sido posto em relevo com a Covid-19. Inúmeros são os frigoríficos no Brasil, sobretudo na região Sul, que protagonizam surtos da doença entre os seus funcionários. Para que a carne continue chegando à mesa da população durante o período de isolamento social, migrantes e indígenas, que formam parte de um contingente de mão de obra barata desse setor, têm sido expostos às contaminações. Atualmente, elas respondem robustamente pela interiorização dos casos da doença, e via de regra como alhures, vitimam quem já sofre em razão de outras cargas de vulnerabilidade. ${ }^{19}$

Por ameaça, eu penso nos discursos que proclamam que os humanos sejam vítimas da força incontrolável e destruidora de uma natureza que escapa a esse controle total. Os exemplos são inúmeros e vão desde as catástrofes decorrentes dos fenômenos climáticos até às irrupções infecciosas, como no caso das pandemias. O pesadelo do excepcionalismo é o de que "às vezes, os humanos não são nem um pouco protagonistas" (Tsing, 2019, p. 128). E, na falta de traquejo político com outros seres, resta a guerra. Mas não é apenas o novo coronavírus que tem sido tratado como um inimigo, nem a Covid-19 é a primeira dessas "guerras". Esse tipo de enquadramento tem sido uma prática recorrente no universo da saúde. Novamente, o caso do mosquito Aedes aegypti é ilustrativo.

19 Ver, por exemplo, Covid-19... (2020). 
A dita versatilidade desse mosquito faz dele um dos maiores vilões do universo das epidemias, mas também uma das mais sofisticadas tecnologias já fabricadas desde a medicina tropical - motivo pelo qual ele foi convertido em uma infraestrutura de políticas de internacionalização da saúde. ${ }^{20}$ Com ele, a saúde (sua ciência e suas técnicas) pode se internacionalizar (Benchimol, 2001, 2011; Löwy, 2006). Desde a sua confirmação como vetor da febre amarela, em 1902, o mosquito passou a ser visto como aquele elemento-chave que permite que um experimento pule de um contexto para outro, como se fosse neutro. Onde quer que você encontre o Aedes aegypti, você pode levar até ele um saber produzido em outro lugar.

A questão é que os vírus e as bactérias, alguns dos agentes patológicos mais comuns, são invisíveis aos nossos olhos. Então, alguns animais, plantas e vetores, como o caso do mosquito, operam aquilo que na teoria ator-rede ficou conhecido como mediação sociotécnica, funcionando como uma espécie de lente de aumento (Akrich, 1993). Eles materializam ou medeiam a presença do vírus; o mosquito torna o vírus visível (Löwy, 2006). Então, nessa lógica de guerra, o mosquito se torna o alvo porque ele é, digamos assim, o quartel general do vírus - o território do inimigo, e deve ser atacado. Essa militarização da relação com o mosquito também deriva das primeiras intervenções dos Estados Unidos na América Latina, como na independência de Cuba e na construção do Canal do Panamá. Nos dois casos, a febre amarela matava pessoas, incluindo soldados e trabalhadores. Então, quando o general William Gorgas entrou em ação contra a doença, o mosquito se tornou um inimigo, e começou a guerra contra ele: inimigo, território, campanha, vigilância, enfrentamento, controle, combate, erradicação. A semântica militar estava por toda parte e permaneceu (Espinosa, 2009; Löwy, 2006, 2017; McNeill, 2010; Stepan, 2011). Foi o que aconteceu, por exemplo, quando a Fundação Rockefeller realizou a grande campanha contra a febre amarela na América Latina entre os anos 1920 e 1950.

20 Eu tenho em mente que a ideia de infraestrutura, como no trabalho de Susan Star (1999) e Bryan Larkin (2018), refere-se a um dispositivo útil de governança que inclui artefatos, instituições, discursos e ações. Os elementos que formam esse aparato não podem ser reduzidos a algo neutro por onde passa a ciência e a política; antes que isso, uma infraestrutura também é (e faz) política. 
A sua meta era matar o inimigo antes que ele nos matasse - e a grande arma para seu extermínio foi o DDT.

Além disso, os especialistas da Rockefeller estabeleceram um padrão internacional conhecido como "índice de mosquitos" com base em sua característica sinantrópica. Desde então, medir a eficácia dos programas de saúde se baseia no vínculo entre o habitat do mosquito e os hábitos humanos. Na biopolítica das epidemias, o controle eficiente dos vetores envolve sobremaneira a vigilância e o controle conjunto dos humanos e dos territórios que ambos constituem e partilham (Löwy, 1990, 1996, 1999, 2006). E, nesse caminho, alguns quadros se complexificam.

Antes do mosquito, por exemplo, as teorias sobre os miasmas e sobre o contágio endossavam políticas higienistas na América Latina e no Caribe. No Rio de Janeiro, por exemplo, elas levaram à destruição de edifícios residenciais. Os pobres e os negros foram perseguidos e expulsos do centro das cidades sob a acusação de que eram sujos e perigosos. Quer dizer, nem sempre "a lente de aumento" que localiza o inimigo invisível é um mosquito ou outra espécie animal.

Populações pobres, mas também migrantes e refugiados e os chamados grupos de risco são muitas vezes estigmatizados no contexto de crises sanitárias, como sendo os responsáveis por carregar consigo os agentes infecciosos. É o caso da Covid-19 ou do HIV-Aids. Os seus vírus não chegam até nós mediados por um vetor, mas diretamente por meio de um outro humano ou por superfícies e objetos com o seu contato. Nesse caso, esse outro passa a ser visto como alvo. Essa é um das razões pelas quais resiste ainda a homofóbica restrição para a doação de sangue por parte de homens que mantiveram relações sexuais com outros homens em um intervalo de tempo menor que um ano. Desde mais de três décadas, recai sobre homossexuais a acusação de serem um risco para o HIV-Aids. ${ }^{21}$ Também não é por menos que se naturalizam ataques de xenofobia, sugerindo que a Covid-19 seja chinesa ou que fronteiras precisem ser fechadas, especialmente para pessoas que venham de países de fora do norte global. A questão é que a militarização das relações é a verdadeira inimiga (Pimenta, 2018; Segata, 2020b). A vida é mais complexa do que encontros

21 Essa pauta foi retomada pelo Supremo Tribunal Federal em meio à pandemia de Covid-19, às vésperas dos 40 anos da descoberta do HIV-Aids, e a restrição foi derrubada. Ver, por exemplo, D’Agostino e Rodrigues (2020). 
regulados e imaginações de classificação presentes nas atuais conformações da biossegurança. Se há fronteiras entre nações, sociedades, culturas ou espécies, elas devem ser locais de encontros pacíficos e aprendizado conjunto, não de separação. Precisamos de mais políticas de cuidado e de inclusão, não de guerra e exclusão.

\section{Considerações finais}

Ao longo deste trabalho eu apresentei tópicos gerais para pensar a constituição de uma antropologia da biossegurança. A agenda de discussões foi situada em um recorte que intersecta críticas antropológicas às tecnologias de produção e de manipulação da vida, as relações entre humanos, animais e ambientes e a globalização. Afetado pelos debates em torno da pandemia de Covid-19 provocada pelo novo coronavírus, eu busquei explorar uma tendência emergente de uma face da biossegurança, que é a de converter as preocupações com a saúde em um assunto de segurança global.

É certo que a pandemia em curso é um desafio para a antropologia. A natureza episódica e excepcional desse tipo de catástrofe exige respostas imediatas e isso tende a dificultar interpretações locais ou culturalmente situadas. Usualmente, sobressaem os modelos explicativos universalizantes, baseados na biologia (Keck; Kelly; Lynteris, 2019; Rosenberg, 1992). Além disso, como bem afirmaram Keck, Kelly e Lynteris (2019), epidemias e antropologia compartilham histórias complicadas. Ambas serviram por muito tempo como obstáculo, mas também como instrumento de inúmeras formas de expansão imperial. As epidemias foram desde meados do século XIX um mecanismo importante para a descoberta e a inovação científica, entre as quais os avanços da microbiologia e da internacionalização da moderna ciência da saúde.

Os surtos de doenças criaram o contexto e a justificativa para políticas de segregação, reassentamento, quarentena e vigilância populacional. As populações nativas e subalternas foram centrais para o surgimento desse novo campo de investigação científica. Tradições locais, rituais, meios de subsistência e espaços domésticos foram lançados como reservatórios patogênicos e como recursos científicos para a medicina tropical. (Keck; Kelly; Lynteris, 2019, p. 3, tradução minha). 
A antropologia, lembremos, igualmente se beneficiou dos privilégios colonialistas para desenvolver os seus primeiros trabalhos de campo. No entanto, se as colônias do início do século XX foram convertidas em um laboratório para a consolidação de algumas ciências brancas, mais recentemente os Estados pós-coloniais têm sido os protagonistas de uma fabulosa crítica da hegemonia científica através do conhecimento e das práticas localmente situadas. Para Keck, Kelly e Lynteris (2019), essa é a linha que vincula e que tensiona a higiene tropical do passado e os recentes programas de segurança em saúde do século XXI. Foi com essa crítica em mente que ao longo do texto eu procurei levantar pistas para um questionamento de uma máquina imperialista silenciosa que responde pela alcunha de biossegurança. No argumento que apresentei, ela "vazou" dos laboratórios para se tornar um novo modelo de relações políticas internacionais - um poderoso instrumento de governamentalidade em escala global. Isso precisa ser pautado. A minha expectativa é que se desdobrem futuros debates em torno de uma antropologia da biossegurança com uma orientação cada vez mais decolonial.

Neste caminho, cabe reafirmar que emergências em saúde, como é o caso da Covid-19 e o amplo aparato que promete preparação e resposta a cenários avassaladores como o dela, precisam ser analisadas a partir de perspectivas locais, sobretudo firmadas no sul global. Doenças tropicais como o ebola, a dengue, a zika, a chikungunya ou a febre amarela, por exemplo, são desde muito tempo experiências crônicas nos países mais pobres. Elas apenas são convertidas em emergência de saúde pública de interesse internacional - PHEIC - quando batem à porta dos países mais ricos. Além disso, sob a rubrica de biossegurança, políticas e práticas de assepsia e de contenção confundem fronteiras culturais, biológicas e de Estado. Não é por menos que pobres, negros e indígenas - latino-americanos, asiáticos ou africanos -, mas também os micróbios e outros patógenos sejam considerados uma constante ameaça à pureza dos países do norte.

O mesmo se aplica aos problemas ecológicos. Era o que eu tinha em mente quando tratei das "guerras crônicas" neste texto. Se por um lado os protocolos de biossegurança prometem regular e proteger as relações entre espécies e ambientes, por outro eles facilitam a máquina produtivista de otimização da natureza, materializada no confinamento animal e na monocultura. Inúmeros debates que têm aparecido recentemente na agenda do Antropoceno questionam o modo como a intervenção humana tem adoecido a vida do planeta. 
Em cena, sobremaneira, o consumismo acelerado e a sua relação com o aquecimento global e a degradação dos ecossistemas (Bonneuil; Fressoz, 2013; Descola, 2017; Trischler, 2017, entre outros). Mas também são numerosos os chamados a "dividir a conta igualmente entre todos"; a lutar juntos pela Terra que é nossa (Latour, 2020). Acontece que ainda que o conceito de Antropoceno se apresente como um problema global, ele também precisa ser posicionado. Afinal, relações históricas de poder e de desigualdade marcam profundamente a América Latina e outros países do sul (Ulloa, 2017). Se ontem foram os violentos processos colonização e de expropriação que arrasaram as suas paisagens naturais, hoje são as tecnologias de manipulação genética que convertem os países mais pobres em grandes e lucrativas lavouras de plantio de transgênicos e em granjas de animais em confinamento.

Enfim, tratar pandemias e catástrofes ambientais e humanitárias como sendo "uma crise" é fingir que vivemos apenas problemas passageiros - é normalizar a exceção (Latour, 2020; Santos, 2020). A Covid-19 é uma tragédia sem precedentes e o vírus que a provoca não chegou sozinho. Ele veio acompanhado das mudanças climáticas em escala global e de um imenso emaranhado de miséria, sofrimento e falta de empatia que desenham um futuro incerto e amedrontador. São os efeitos de um projeto acelerado e destrutivo para o controle, o aprimoramento e o consumo da natureza convertida em mercadoria (Berardi, 2019; Stengers, 2015). Em outras palavras, o que temos vivido com a Covid-19 é apenas mais um sintoma. A verdadeira doença ainda se chama capitalismo.

\section{Referências}

ADAMS, V. Metrics of the global sovereign: numbers and stories in global health. In: ADAMS, V. Metrics: what counts in global health. Durham: Duke University Press, 2016. p. 19-56.

AKRICH, M. Les formes de la médiation technique. Réseaux, Paris, v. 60, p. 87-98, 1993.

AUGUSTO, L. et al. Programa de erradicação do Aedes aegypti: inócuo e perigoso (e ainda perdulário). Cadernos de Saúde Pública, Rio de Janeiro, v. 14, n. 4, p. 876877, 1998.

BECK, U. The risk society: towards a new modernity. London: Sage, 1992. 
BENCHIMOL, J. Febre amarela: a doença e a vacina, uma história inacabada. Rio de Janeiro: Editora Fiocruz, 2001.

BENCHIMOL, J. Mosquitos, doenças e ambientes em perspectiva. In: SIMPÓSIO NACIONAL DE HISTÓRIA, 26., 2011, São Paulo. Anais... São Paulo: Associação Nacional de História, 2011. p. 1-15.

BERARDI, F. Depois do futuro. Rio de Janeiro: Ubu, 2019.

BEVILAQUA, C. B. Espécies invasoras e fronteiras nacionais: uma reflexão sobre limites do estado. Anthropológicas, Recife, v. 24, p. 103-123, 2014.

BIRUK, C. When numbers travel: the politics of making evidence-based policy. In: BIRUK, C. Cooking data: culture and politics in an African research world. Durham: Duke University Press, 2018. p. 166-200.

BLANCHETTE, A. Porkopolis: American animality, standardized life, and the factory farm. Durham: Duke University Press, 2020.

BOLSONARO volta a criticar o isolamento social contra o coronavírus. O Globo, 16 maio 2020. Disponível em: https://oglobo.globo.com/brasil/bolsonaro-volta-criticar-isolamento-social-contra-coronavirus-24430964. Acesso em: 17 maio 2020.

BONNEUIL, C.; FRESSOZ, J.-B. L'Evénement Anthropocène: la Terre, l'histoire et nous. Paris: Seuil, 2013.

BRASIL. Lei $\mathrm{n}^{\circ} 11.105$, de 24 de março de 2005. Regulamenta os incisos II, IV e V do $\S 1^{\circ}$ do art. 225 da Constituição Federal, estabelece normas de segurança e mecanismos de fiscalização de atividades que envolvam organismos geneticamente modificados - OGM e seus derivados, cria o Conselho Nacional de Biossegurança - CNBS, reestrutura a Comissão Técnica Nacional de Biossegurança - CTNBio, dispõe sobre a Política Nacional de Biossegurança - PNB, revoga a Lei $n^{\circ} 8.974$, de 5 de janeiro de 1995, e a Medida Provisória ${ }^{\circ} 2.191-9$, de 23 de agosto de 2001, e os arts. $5^{\circ}, 6^{\circ}, 7^{\circ}$, $8^{\circ}, 9^{\circ}, 10$ e 16 da Lei $n^{\circ} 10.814$, de 15 de dezembro de 2003 , e dá outras providências. Diário Oficial da União, Brasília, 28 mar. 2005a. Seção 1, p. 1-5.

BRASIL. Ministério do Trabalho e Emprego. Portaria n. 485, de 11 de novembro de 2005. Aprova a Norma Regulamentadora n. 32 que dispõe sobre a Segurança e Saúde no Trabalho em Estabelecimentos de Saúde. Diário Oficial da União, Brasília, 16 nov. 2005b. Seção 1, p. 80-94.

BRASIL passa de 50 mil mortes por coronavírus, mostra consórcio de veículos de imprensa. G1, 20 jun. 2020. Disponível em: https://g1.globo.com/bemestar/coronavirus/noticia/2020/06/20/brasil-passa-de-50-mil-mortes-por-coronavirus-mostra-consorcio-de-veiculos-de-imprensa-sao-964-em-24-horas.ghtml. Acesso em: 20 jun. 2020. 
CADUFF, C. On the verge of death: visions of biological vulnerability. Annual Review of Anthropology, Stanford, v. 43, p. 105-121, 2014a.

CADUFF, C. Sick weather ahead: on data-mining, crowd-sourcing and white noise. Cambridge Anthropology, Cambridge, v. 32, n. 1, p. 32-46, 2014b.

CADUFF, C. The pandemic perhaps: dramatic events in a public culture of danger. Oakland: University of California Press, 2015.

CALLON, M.; LASCOUMES, P.; BARTHE, Y. Agir dans un monde incertain: essais sur la démocratie technique. Paris: Seuil, 2001.

CARMO, E. H.; PENNA, G.; OLIVEIRA, W. K. Emergências de saúde pública: conceito, caracterização, preparação e resposta. Estudos Avançados, São Paulo, v. 22, n. 64, p. 19-32, 2008.

CESARINO, L. Acendendo as luzes da ciência para iluminar o caminho do progresso: uma análise simétrica da Lei de Biossegurança brasileira. 2006. Dissertação (Mestrado em Antropologia Social) - Departamento de Antropologia, Universidade de Brasília, Brasília, 2006.

CESARINO, L. Nas fronteiras do "humano": os debates britânico e brasileiro sobre a pesquisa com embriões. Mana, Rio de Janeiro, v. 13, n. 2, p. 347-380, 2007.

CEYHAN, A. Les technologies européennes de contrôle de l'immigration: vers une gestion électronique des “personnes à risque”. Réseaux, Paris, v. 159, p. 131-150, 2010.

CHINA coronavirus death toll rises to 17; WHO considers declaring global health emergency. Los Angeles Times, 22 Jan. 2020. Disponível em: https://www.latimes. com/science/story/2020-01-22/wuhan-china-deadly-coronavirus. Acesso em: 23 jan. 2020.

COLLIER, S. Post-Soviet social: neoliberalism, social modernity, biopolitics. Princeton: Princeton University Press, 2011.

COLLIER, S.; LAKOFF, A. The problem of securing health: mapping the multiplicities of biosecurity. In: COLLIER, S.; LAKOFF, A. (ed.). Biosecurity interventions: global health and security in question. New York: Columbia University Press, 2008. p. 7-32.

COLLIER, S.; LAKOFF, A.; RABINOW, P. Biosecurity: towards an anthropology of the contemporary. Anthropology Today, London, v. 20, n. 5, p. 3-7, 2004.

CORONAVÍRUS: CONDOMÍNIO em SP tentou segregar chineses como 'medida de prevenção'. BBC Brasil, 5 fev. 2020. Disponível em: https://www.bbc.com/portuguese/ brasil-51379835. Acesso em: 5 fev. 2020. 
CORONAVIRUS DEATH toll climbs in China, and a lockdown widens. The New York Times, 23 Jan. 2020. Disponível em: https://www.nytimes.com/2020/01/23/world/ asia/china-coronavirus.html. Acesso em: 23 jan. 2020.

CORONAVÍRUS PODE ter sido transmitido por sopa de morcego e carne de cobra. Veja, 23 jan. 2020. Disponível em: https://veja.abril.com.br/saude/coronavirus-pode-ter-sido-transmitido-por-sopa-de-morcego-e-carne-de-cobra/. Acesso em: 20 jun. 2020.

COVID-19: 30\% dos casos confirmados no RS são de trabalhadores de frigoríficos. CUT, 2 jun. 2020. Disponível em: https://www.cut.org.br/noticias/covid-19-30-dos-casos-confirmados-no-rs-sao-de-trabalhadores-de-frigorificos-11f4. Acesso em: 20 jun. 2020.

CRAVEIRO, R. Trump sugere injeção de desinfetante contra o coronavírus; médicos criticam. Correio Braziliense, 25 abr. 2020. Disponível em: https://www.correiobraziliense.com.br/app/noticia/mundo/2020/04/25/interna_mundo,848146/trump-sugere-injecao-de-desinfetante-contra-o-coronavirus-medicos-cri.shtml. Acesso em: 1 maio 2020.

CUETO, M. Saúde global: uma breve história. Rio de Janeiro: Editora Fiocruz, 2015.

DAS, V. Critical events: an anthropological perspective on contemporary India. Oxford: Oxford University Press, 1995.

D'AGOSTINO, R.; RODRIGUES, M. Supremo Tribunal Federal derruba restrições à doação de sangue por homens gays. G1, 9 maio 2020. Disponível em: https://g1.globo. com/politica/noticia/2020/05/09/supremo-tribunal-federal-derruba-restricoes-a-doacao-de-sangue-por-homens-gays.ghtml. Acesso em: 11 maio 2020.

DESCOLA, P. ¿Humano, demasiado humano?. Desacatos: Revista de Ciencias Sociales, Ciudad de México, v. 54, p. 16-27, 2017.

DÉTURCHE, J. As vacas da discórdia: gestão e raça do rebanho entre os criadores de vacas montbéliardes na Haute-Savoie - França. Ilha: Revista de Antropologia, Florianópolis, v. 14, p. 139-169, 2012.

'DEUS é brasileiro e a cura tá aí', diz Bolsonaro sobre remédio ainda em teste contra Covid-19. O Globo, 29 mar. 2020. Disponível em: https://oglobo.globo.com/sociedade/ coronavirus/deus-brasileiro-a-cura-ta-ai-diz-bolsonaro-sobre-remedio-ainda-em-teste-contra-covid-19-1-24337060. Acesso em: 1 maio 2020.

DINIZ, D.; BRITO, L. Uma epidemia sem fim: zika e mulheres. In: RIFIOTIS, T.; SEGATA, J. (org.). Políticas etnográficas no campo da moral. Porto Alegre: UFRGS, 2018. p. 169-183. 
DOMINGOS, R. É \#FAKE que chá com mistura de jambu, limão, alho e paracetamol cura a Covid-19. G1, 24 abr. 2020. Disponível em: https://g1.globo.com/ fato-ou-fake/coronavirus/noticia/2020/04/24/e-fake-que-cha-com-mistura-de-jambu-limao-alho-e-paracetamol-cura-a-covid-19.ghtml. Acesso em: 1 maio 2020.

DONALDSON, A. Biosecurity after the event: risk politics and animal disease. Environment and Planning A: Economy and Space, Los Angeles, v. 40, n. 7, p. 1552-1567, 2008.

ESPINOSA, M. Epidemic invasions: yellow fever and the limits of Cuban independence, 1878-1930. Chicago: The University of Chicago Press, 2009.

FASSIN, D. Life: a critical user's manual. Boston: Polity, 2018.

FIDLER, D.; GOSTIN, L. Biosecurity in the global age. Stanford: Stanford University Press, 2008.

FISCHER, M. Emergent forms of life and the anthropological voice. Durham: Duke University Press, 2003.

FONSECA, C. Parentesco, tecnologia e lei na era do DNA. Rio de Janeiro: EdUERJ, 2014.

FOUCAULT, M. Segurança, território, população: curso dado no Collège de France (1977-1978). São Paulo: Martins Fontes, 2008.

FOUCAULT, M. O nascimento da biopolítica. Lisboa: Edições 70, 2010.

FRANKLIN, S.; LOCK, M. Remaking life and death: toward an anthropology of the biosciences. Santa Fe: School of American Research Press, 2003.

GONZÁLEZ, R. J. Seeing into hearts and minds (part 1): the Pentagon's quest for a 'social radar'; Seeing into hearts and minds (part 2): 'Big data', algorithms, and computational counterinsurgency. Anthropology Today, London, v. 31, n. 3, p. 8-18, 2015.

GUO, H.; LUO, G.; GAO, S.-J. Snakes could be the source of the Wuhan coronavirus outbreak. CNN, 22 Jan. 2020. Disponível em: https://www.cnn.com/2020/01/22/ health/snakes-wuhan-coronavirus-outbreak-conversation-partner/index.html. Acesso em: 24 jan. 2020.

HARAWAY, D. Anthropocene, Capitalocene, Plantationocene, Chthulucene: making kin. Environmental Humanities, Sydney, v. 6, p. 159-165, 2015.

HELMREICH, S. Biosecurity: a response to Collier, Lakoff \& Rabinow AT20[5]. Anthropology Today, London, v. 21, n. 2, p. 21, 2005.

KECK, F. Un monde grippé. Paris: Flammarion, 2010. 
KECK, F.; KELLY, A. H.; LYNTERIS, C. Introduction: the anthropology of epidemics. In: KELLY, A. H.; KECK, F.; LYNTERIS, C. (ed.). The anthropology of epidemics. London: Routledge, 2019. p. 1-23.

LAKOFF, A. From population to vital system: national security and the changing object of public health. In: COLLIER, S.; LAKOFF, A. (ed.). Biosecurity interventions: global health and security in question. New York: Columbia University Press, 2008. p. 33-60.

LAKOFF, A. Unprepared: global health in a time of emergency. Oakland: University of California Press, 2017.

LANGDON, E. J.; FOLLÉR, M.-L.; MALUF, S. Um balanço da antropologia da saúde no Brasil e seus diálogos com as antropologias mundiais. Anuário Antropológico, Brasília, v. 51, p. 51-89, 2012.

LANGLITZ, N. Biosecurity: a response to Helmreich, AT 21[2]. Anthropology Today, London, v. 21, n. 6, p. 20-21, 2005.

LAPEGNA, P. La Argentina transgénica: de la resistencia a la adaptación, una etnografía de las poblaciones campesinas. Buenos Aires: Siglo Veintiuno, 2019.

LAPEGNA, P.; OTERO, G. Cultivos transgénicos en América Latina: expropriación, valor negativo y Estado. Estudios Críticos del Desarollo, Ciudad de México, v. 6, n. 2, 2016, p. 19-43.

LARKIN, B. Promising forms: the political aesthetics of infrastructure. In: ANAND, N.; GUPTA, A.; APPEL, H. (ed.). The promise of infrastructure. Durham: Duke University Press, 2018. p. 175-202.

LATOUR, B. Diante de Gaia: oito conferências sobre a natureza do Antropoceno. São Paulo: Ubu Editora; Rio de Janeiro: Ateliê de Humanidades, 2020.

LEAL, N. S. Nome aos bois: zebus e zebuzeiros em uma pecuária brasileira de elite. São Paulo: Hucitec, 2016.

LEWGOY, B.; SEGATA, J. A persistência da exceção humana. Vivência: Revista de Antropologia, Natal, n. 49, p. 155-164, 2017.

LIEN, M. E. Becoming salmon: aquaculture and the domestication of a fish. Oakland: University of California Press, 2015.

LISTER, T.; SHUKLA, S.; BOBILLE, F. Pandemia de coronavírus desencadeia disputa global por máscaras de proteção. CNN Brasil, 5 abr. 2020. Disponível em: https:// www.cnnbrasil.com.br/internacional/2020/04/05/pandemia-de-coronavirus-desencadeia-disputa-global-por-mascaras-de-protecao. Acesso em: 7 maio 2020. 
LÖWY, I. Yellow fever in Rio de Janeiro and the Pasteur Institute Mission (19011905): the transfer of science to the periphery. Medical History, Cambridge, v. 34, p. 144-163, 1990.

LÖWY, I. Éradication de vecteur contre vaccination: la Fondation Rockefeller et la fièvre jaune au Brésil, 1923-1939. In: WAAST, R. (ed.). Médecines et santé. Paris: Orstom Édition: IRD, 1996. p. 91-108. (Les sciences hors d'Occident au XXe Siècle, vol. 4).

LÖWY, I. Representação e intervenção em saúde pública: vírus, mosquitos e especialistas da Fundação Rockefeller no Brasil. História, Ciências, Saúde - Manguinhos, Rio de Janeiro, v. 5, n. 3, p. 647-677, 1999.

LÖWY, I. Vírus, mosquitos e modernidade: a febre amarela no Brasil entre ciência e política. Rio de Janeiro: Editora Fiocruz, 2006.

LÖWY, I. Leaking containers: success and failure in controlling the mosquito Aedes aegypti in Brazil. American Journal of Public Health, Washington DC, v. 107, n. 4, p. 517524, 2017.

MANCERON, V.; ROUÉ, M. Introduction: les animaux de la discorde. Ethnologie française, Paris, v. 39, n. 1, p. 5-10, 2009.

MARQUES, R. de C.; SILVEIRA, A. J. T.; PIMENTA, D. N. A pandemia de Covid-19: interseções e desafios para a história da saúde e do tempo presente. In: SIQUEIRA, T. R. et al. (org.). Coleção história do tempo presente: volume 3. Boa Vista: Editora da UFRR, 2020. p. 225-249.

MASON, K. A. H1N1 is not a Chinese virus: the racialization of people and viruses in post-SARS China. Studies in Comparative International Development, Providence, v. 50, n. 4, p. 500-518, 2015.

MASON, K. A. Infectious change: reinventing Chinese public health after an epidemic. Stanford: Stanford University Press, 2016.

MATTA, G. C.; MORENO, A. B. Saúde global: uma analise sobre as relações entre os processos de globalização e o uso dos indicadores de saúde. Interface: Comunicação, Saúde e Atenção, Botucatu, v. 18, n. 48, p. 9-22, 2014.

McNEILL, J. R. Mosquito empires: ecology and war in the greater Caribbean, 1620-1914. Cambridge: Cambridge University Press, 2010.

MENASCHE, R. Os grãos da discórdia e o risco à mesa: um estudo antropológico das representações sociais sobre os cultivos e alimentos transgênicos no Rio Grande do Sul. 2003. Tese (Doutorado em Antropologia Social) - Instituto de Filosofia e Ciências Humanas, Universidade Federal do Rio Grande do Sul, Porto Alegre, 2003. 
MOL, A. The body multiple: ontology in medical practice. Durham: Duke University Press, 2002.

MORAN-THOMAS, A. Traveling with sugar: chronicles of a global epidemic. Oakland: University of California Press, 2019.

NADING, A. Local biologies, leaky things, and the chemical infrastructure of global health. Medical Anthropology, London, v. 36, n. 2, p. 141-156, 2017.

NEVES, T. P. et al. O conceito de biossegurança à luz da ciência pós-normal: avanços e perspectivas para a saúde coletiva. Saúde e Sociedade, São Paulo, v. 16, n. 3, p. 158-168, 2007.

OMS DECLARA Europa como novo epicentro de pandemia do coronavírus. O Globo, 13 mar. 2020. Disponível em: https://oglobo.globo.com/sociedade/oms-declara-europa-como-novo-epicentro-de-pandemia-do-coronavirus-24303239. Acesso em: 15 mar. 2020.

ORGAZ, C. J. Coronavírus: como o avanço da doença já impacta economia do Brasil e do mundo. BBC Brasil, 3 fev. 2020. Disponível em: https://www.bbc.com/portuguese/ internacional-51358563. Acesso em: 5 fev. 2020.

PACIENTE em MG 'não se enquadra na definição de caso suspeito de coronavírus', diz ministério. G1, 22 jan. 2020. Disponível em: https://gl.globo.com/ciencia-e-saude/ noticia/2020/01/22/paciente-em-mg-nao-se-enquadra-na-definicao-de-caso-suspeito-de-coronavirus-diz-ministerio.ghtml. Acesso em: 23 jan. 2020.

PAÍSES fecham fronteiras para viajantes que passaram pela China; Brasil ainda não tomou decisão. BBC Brasil, 1 fev. 2020. Disponível em: https://www.bbc.com/portuguese/internacional-51341825. Acesso em: 5 fev. 2020.

PEDUZZI, P. Esgoto pode indicar percentual de contaminados pela covid-19. Agência Brasil, 22 maio 2020. Disponível em: https://agenciabrasil.ebc.com.br/saude/ noticia/2020-05/esgoto-pode-indicar-percentual-de-contaminados-pela-covid-19. Acesso em: 20 jun. 2020.

PEREIRA, E. F. As taxas de letalidade da COVID-19 e o afrouxamento das quarentenas. Boletim Cientistas Sociais e o Coronavírus, São Paulo, n. 30, 2020. Disponível em: https:// www.anpocs.com/index.php/ciencias-sociais/destaques/2344-boletim-n-30-cientistas-sociais-e-o-coronavirus. Acesso em: 10 maio 2020.

PETRYNA, A. Life exposed: biological citizens after Chernobyl. Princeton: Princeton University Press, 2003.

PIMENTA, D. "If you suspect a case of Ebola... free call 177": ensaio sobre a militarização da saúde em Serra Leoa no período da epidemia de Ebola (2014-2016). Cadernos de Campo, São Paulo, v. 27, n. 1, p. 85-117, 2018. 
PIMENTA, D. O cuidado perigoso: tramas de afeto e risco na Serra Leoa (A epidemia do ebola contada pelas mulheres, vivas e mortas). 2019. Tese (Doutorado em Antropologia) - Faculdade de Filosofia, Letras e Ciências Humanas, Universidade de São Paulo, São Paulo, 2019.

PINHEIRO-MACHADO, R. Coronavírus expõe a nossa desinformação sobre a China, o maior fenômeno econômico dos nossos tempos. The Intercept Brasil, 28 jan. 2020. Disponível em: https://theintercept.com/2020/01/28/coronavirus-desinformacao-china/. Acesso em: 30 jan. 2020.

RABINOW, P.; ROSE, N. Biopower today. BioSocieties, London, n. 1, p. 195-217, 2006.

REITH, G. Uncertain times: the notion of 'risk' and the development of modernity. Time \& Society, London, v. 13, n. 2-3, p. 383-402, 2004.

RICHTER, V. Identificação genética e crime: a introdução dos bancos de DNA no Brasil. 2016. Tese (Doutorado em Antropologia Social) - Instituto de Filosofia e Ciências Humanas, Universidade Federal do Rio Grande do Sul, Porto Alegre, 2016.

ROCHA, S. et al. Biossegurança, proteção ambiental e saúde: compondo o mosaico. Ciência \& Saúde Coletiva, Rio de Janeiro, v. 17, n. 2, p. 287-292, 2012.

ROHDEN, F. O império dos hormônios e a construção das diferenças de gênero. História, Ciências, Saúde - Manguinhos, Rio de Janeiro, v. 15, p. 133-152, 2008.

ROHDEN, F. Adjusting hormones and constructing desires: new materialisations of female sexuality in Brazil. Culture Health \& Sexuality, London, v. 1, p. 1-14, 2019.

ROSE, N. A política da própria vida: biomedicina, poder e subjetividade no século XXI. São Paulo: Paulus, 2013.

ROSENBERG, C. E. Explaining epidemics. Cambridge: Cambridge University Press, 1992.

SANTOS, B. S. A cruel pedagogia do vírus. Coimbra: Almedina, 2020.

SANTOS, R. V.; GIBBON, S.; BELTRÃO, J. (org.). Identidades emergentes, genética e saúde: perspectivas antropológicas. Rio de Janeiro: Garamond: Fiocruz, 2012.

SEGATA, J. O Aedes aegypti e o digital. Horizontes Antropológicos, Porto Alegre, ano 23, n. 48, p. 19-48, 2017.

SEGATA, J. El mosquito-oráculo y otras tecnologías. Tabula Rasa, Bogotá, v. 32, p. 103125, 2019.

SEGATA, J. Covid-19: escalas da pandemia, escalas da antropologia. Boletim Cientistas Sociais e o Coronavírus, São Paulo, n. 2, 2020a. Disponível em: http://anpocs.com/ index.php/ciencias-sociais/destaques/2307-boletim-n-1-cientistas-sociais-o-o-coronavirus-2. Acesso em: 10 maio 2020. 
SEGATA, J. Covid-19, crystal balls, and the epidemic imagination. American Anthropologist, Arlington, Public Anthropology Series, 2020b. Disponível em: http://www. americananthropologist.org/2020/07/02/covid-19-crystal-balls-and-the-epidemic-imagination/. Acesso em: 02 de julho de 2020.

SIBILIA, P. O homem pós-orgânico: a alquimia dos corpos e das almas à luz das tecnologias digitais. 2. ed. Rio de Janeiro: Contraponto, 2015.

SORDI, C. Quem governa a invasão biológica? Um problema para a antropologia. Novos Debates: Fórum de Debates em Antropologia, Brasília, v. 2, p. 270-276, 2015.

SORDI, C. Presenças ferais: invasão biológica, javalis asselvajados (Sus scrofa) e seus contextos no Brasil Meridional em perspectiva antropológica. 2017. Tese (Doutorado em Antropologia Social) - Instituto de Filosofia e Ciências Humanas, Universidade Federal do Rio Grande do Sul, Porto Alegre, 2017.

SOUZA, A. de. 'Coronavírus vem se comportando de forma semelhante ao que ocorreu na Itália', diz chefe de imunização da Saúde. O Globo, 13 mar. 2020. Disponível em: https://oglobo.globo.com/sociedade/coronavirus/coronavirus-vem-se-comportando-de-forma-semelhante-ao-que-ocorreu-na-italia-diz-chefe-de-imunizacao-da-saude-24310968. Acesso em: 20 abr. 2020.

STENGERS, I. No tempo das catástrofes: resistir à barbárie que se aproxima. São Paulo: Cosac Naify, 2015.

STEPAN, N. Eradication: ridding the world of diseases forever?. London: Reaktion Books, 2011.

STAR, S. The ethnography of infrastructure. American Behavioral Scientist, New York, v. 43, n. 3, p. 377-391, 1999.

STRATHERN, M. Kinship, law and the unexpected: relatives are always a surprise. Cambridge: Cambridge University Press, 2005.

TRISCHLER, H. El Antropoceno, ¿un concepto geológico o cultural, o ambos?. Desacatos: Revista de Ciencias Sociales, Ciudad de México, v. 54, p. 40-57, 2017.

TSING, A. L. Friction: an ethnography of global connection. Princeton: Princeton University Press, 2005.

TSING, A. L. Socialidade mais do que humana: um chamado para a descrição crítica. In: TSING, A. L. Viver nas ruínas: paisagens multiespécies no Antropoceno. Brasília: IEAB Mil Folhas, 2019. p. 119-140.

ULLOA, A. Dinámicas ambientales y extractivas en el siglo XXI: ¿es la época del Antropoceno o del Capitoloceno en Latinoamerica?. Desacatos: Revista de Ciencias Sociales, Ciudad de México, v. 54, p. 58-73, 2017. 
UNA-SUS. Organização Mundial de Saúde declara pandemia do novo Coronavírus. 11 mar. 2020. Disponível em: https://www.unasus.gov.br/noticia/organizacao-mundial-de-saude-declara-pandemia-de-coronavirus. Acesso em: 15 mar. 2020.

VALFRÉ, V.; VARGAS, M. Interino da Saúde vai liberar cloroquina a mando de Bolsonaro. UOL, 16 maio 2020. Disponível em: https://noticias.uol.com.br/ultimas-noticias/agencia-estado/2020/05/16/interino-vai-liberar-cloroquina-a-mando-de-bolsonaro.htm. Acesso em: 17 maio 2020.

VON SCHNITZER, A. Traveling technologies: infrastructures, ethical regimes, and the materiality of politics in South Africa. Cultural Anthropology, Arlington, v. 8, n. 4, p. 670-693, 2013.

WORLD HEALTH ORGANIZATION. Statement on the second meeting of the International Health Regulations (2005) Emergency Committee regarding the outbreak of novel coronavirus (2019-nCoV). Geneva, 30 Jan. 2020a. Disponível em: https://www.who. int/news-room/detail/30-01-2020-statement-on-the-second-meeting-of-the-international-health-regulations-(2005)-emergency-committee-regarding-the-outbreak-of-novel-coronavirus-(2019-ncov). Acesso em: 4 fev. 2020.

WORLD HEALTH ORGANIZATION. Coronavirus press conference 11 February, 2020. Geneva, 2020b. Disponível em: https://www.who.int/docs/default-source/coronaviruse/transcripts/who-audio-emergencies-coronavirus-full-press-conference-11feb2020-final.pdf?sfvrsn=e2019136_2. Acesso em: 15 fev. 2020.

ZHANG, Y. et al. The epidemiological characteristics of an outbreak of 2019 Novel Coronavirus Diseases (COVID-19) in China. Chinese Journal of Epidemiology, Beijing, v. 41, n. 2, p. 145-151, 2020.

Recebido: 31/05/2020 Aceito: 25/06/2020 | Received:5/31/2020 Accepted:6/25/2020 